\title{
ЗАСТОСУВАННЯ ЛІНГВОКРАЇНОЗНАВЧИХ МАТЕРІАЛІВ У ВИКЛАДАННІ УКРАЇНСЬКӦ̈ МОВИ ЯК ІНОЗЕМНОї
}

\begin{abstract}
Статтю присвячено проблемі використання лінгвокраӥнознавчих матеріалів у процесі навчання іноземних студентів української мови. Автор обтрунтовує доцільність застосування текстів, щяо містять лінгвокраїнознавчу інформацію, окреслює критерії відбору лінгвокраїнознавчих текстів, наводить приклади роботи з текстами.

Ключові слова: лінгвокраӥнознавчий матеріал, іноземні студенти, украӥнська мова, сочіолінгвістична компетенція.
\end{abstract}

Статья посвящена проблеме использования лингвострановедческих материалов в процессе обучения иностранных студентов украинскому языку. Автор обосновывает иелесообразность применения текстов, содержащих лингвострановедческую информацию, определяет критерии отбора лингвострановедческих текстов, приводит примеры работы с текстами.

Ключевые слова: лингвострановедческий материал, иностранные студенты, украинский язык, соииолингвистическая компетенция.

The article is devoted to the problem of using linguistic-geographical materials in teaching process of foreign students the Ukrainian language. The author proves the necessity of using texts, that contain linguistic-geographical information, author outlines the selecting criteria for linguistic-geographical texts, gives examples of working with the texts.

Key words: linguistic-geographical material, foreign students, Ukrainian language, sociolinguistic competence.

Сучасна концепція мовної освіти акцентує увагу на необхідності в процесі викладання будь-якої мови як іноземної ознайомлення 3 культурою інших країн, що актуалізує проблему використання лінгвокраїнознавчих матеріалів у процесі навчання української мови як іноземної. Акумулюючи в собі всі вияви буття етносу, мова є невичерпним джерелом інформації про історію, звичаї, традиції матеріальної культури й духовного життя нації. Пізнання студентом мови, як феномену національної культури, сприяє формуванню соціолінгвістичної компетенції - здатності користуватися мовними формами, доцільними в певному соціолінгвістичному контексті, відповідно, надає можливість адекватної взаємодії та взаєморозуміння людей в умовах іншомовної культури. Чимало вітчизняних та зарубіжних науковців (Н. Бідненко, Г. Глубоковських, Н. Зінукова, В. Сотниченко, Ю. Стиркіна, Н. Алмазова, Н. Андронкіна, Г. Томахін та ін.) займалися проблемою лінгвокраїнознавчого підходу до оволодіння іноземними мовами.

Mema cmammi: дослідити можливості використання лінгвокраїнознавчих матеріалів у процесі викладання української мови іноземним студентам нефілологічних спеціальностей, окреслити критерії відбору лінгвокраїнознавчих текстів, з’ясувати їх місце в навчальному процесі.

Важливим $€$ розуміння взаємопов'язаності мови й певних виявів національної культури (національний костюм, деталі поведінки, етикет, жести, дотримання відомих обрядів, звичаїв), що засвідчують належність людини до того чи того народу. Мова накопичує й закріплює у своїх одиницях (головним чином - у словах, у стійких сполуках і фразеологічних зворотах) історичний досвід народу, стає адекватним відображенням його внутрішнього світу, неповторності менталітету. Процес вивчення іноземної мови є невіддільними від ознайомлення 3 іншомовною культурою, оскільки мова ніби ретранслятор передає надбання національної культури від покоління до покоління, представникам інших етнічних соціумів [1].

Питанням відбору та прийомів подачі інформації про країну, мова якої вивчається, займається лінгвокраїнознавство. Як аспект методики викладання іноземних мов, лінгвокраїнознавство відбиває національно-культурний компонент мовного матеріалу. Без засвоєння значного обсягу немовної інформації неможливо отримати якісну мовну освіту та досягти взаєморозуміння між мовцями, що знаходяться на різних рівнях володіння інформацією про навколишню дійсність. Нині методисти усвідомлюють необхідність використання лінгвокраїнознавчого підходу як важливого принципу викладання іноземної мови для надання студентам необхідних знань про специфіку іншомовної країни.

Наявність у лексиці національно-культурного компонента, притаманного тільки певній мові, свідчить про належність лексеми до лінгвокраїнознавчого матеріалу. Застосування в процесі викладання української мови як іноземної матеріалів 3 лінгвокраїнознавства сприяє процесу акультурації студентів-іноземців, тобто допомагає адаптуватися до нового мовно-культурного середовища. Наприклад, іноземні студенти першого курсу вже орієнтуються серед найменувань предметів та явищ місцевого традиційного побуту (борщ, Масляна, млинець, сало, рушник тощо). Використання лінгвокраїнознавчих матеріалів стимулює мотивацію студентів, формує й підтримує інтерес до вивчення іноземної мови. До робочого лінгвокраїнознавчого матеріалу належать: автентичні тексти (уривки з художньої прози, статті з журналів та газет), автентичні діалоги, вірші, пісні. Розширенню обізнаності студентів у всіх сферах життєдіяльності сприятиме також перегляд телепередач, документальних та художніх фільмів мовою, яка вивчається. 
Набуваючи останнім часом все більшої значущості в процесі навчання іноземних мовах, текст країнознавчого характеру розглядається як одна 3 важливих форм комунікації, яка $є$ механізмом становлення індивіда як соціальної особистості. Іноземна мова для студентів нефілологічних спеціальностей, на думку А. Бронської, є одним із найскладніших предметів, причому труднощі викликає вербальне вираження змісту предмета, наприклад, переказ тексту, насиченого порівняннями, метафорами, образними висловами. «Більшість студентів-нефілологів віддають перевагу науково-популярним і лінгвокраїнознавчим текстам. Це пояснюється не тільки більш зрозумілою лексикою, а й синтаксичною побудовою, яка властива науковому тексту, де взагалі відсутні неповні, називні речення, що не завжди зрозумілі іноземцям», - зазначає дослідниця [3, с. 23]. Такі тексти мають на меті ознайомити студентів 3 реаліями іншомовної країни, подати знання в галузі географії, освіти, культури тощо.

Відбір текстів лінгвокраїнознавчого характеру здійснюється за такими критеріями:

- автентичність (продукується в середовищі, мова якого вивчається);

- країнознавча насиченість (обсяг лінгвокраїнознавчих відомостей у тексті);

- актуальність (сучасне та актуальне для студента інформативне наповнення);

- типовість (систематичне відтворення в типових комунікативних ситуаціях).

Наведемо орієнтовний перелік тем, які пропонуємо іноземним студентам. Усі тексти безпосередньо стосуються України, є змістовно значущими та актуальними для студентів: «Перші поселення на території України», «Заснування Києва. Перші князі», «Україна: назва землі й держави», «Україна», «Державний Герб України», «Державний Гімн України», «Державний Прапор України», «Конституція України», «Державний устрій України», «Географічне положення України», «Клімат України», «Визначні пам'ятки України», «Київ - столиця України», «Визначні пам'ятки Києва», «Золоті ворота», «Софіївський Собор», «Києво-Печерська Лавра», «Володимирський Собор», «Пам’ятник засновникам Києва», «Хрещатик», «Андріївський узвіз», «Луганськ», «Пам’ятний знак Божої Матері», «Пам'ятник Володимиру Далю», «Український вінок», «Рушник», «Козаки», «Краса української пісні», «Безмежність української мови», «Великі українці» та інші.

Засвоєння запропонованого матеріалу забезпечить студентів систематизованими й досить повними відомостями про Україну як країну, мова якої вивчається, а також сприятиме вдосконаленню знань української мови.

Як бачимо, тексти охоплюють питання з історії утворення держави, походження назви «Україна», iii державного устрою, кліматичних умов, міста Києва, пам'яток, видатних людей України. Крім цього, пропонуються тексти, що стосуються міста Луганська та його окремих пам'яток. Акцентування уваги на місті Луганську зумовлено перебуванням тут іноземних студентів під час навчання, інтересом до міста, із яким буде пов'язане їхне життя в найближчі декілька років. Використовуються також тексти, які ознайомлюють іноземних студентів із віруваннями та традиціями, укладом життя українського народу.

У сучасній методиці загальноприйнятою є думка про те, що робота 3 текстами для читання в іншомовній аудиторії має проводитися щонайменше у три етапи:

- передтекстова частина (пояснення нових лексичних одиниць, зняття труднощів перед читанням);

- власне читання;

- післятекстова робота (виконання вправ на перевірку розуміння прочитаного).

Характер завдань може варіюватися в залежності від таких чинників як мета, вид читання, тип матеріалу, ступінь складності тексту тощо.

Кожен запропонований текст супроводжується передтекстовим та післятекстовим комплексом вправ, орієнтованих, окрім ознайомлення з українською культурою, на розвиток у студентів навичок усного мовлення, збагачення словникового запасу, вдосконалення граматичних навичок. Наведемо приклад роботи з текстами лінгвокраїнознавчого характеру. Перед опрацюванням тексту «Козаки» студентам пропонується обговорення репродукції знаменитої картини російського художника Іллі Рєпіна «Запорожці пишуть листа турецькому султану», а також елементів козацького одягу; передбачається робота 3 лексикою, що характеризується наявністю національно-культурного компонента: козак, Січ, чайка, шаровари тощо.

Завдання:

1. Знайдіть подані слова в словнику, запам'ятайте їх значення: вільний, незалежний, море, суша, випадок, верх, дно, човен, ворог.

2. Утворіть словосполучення, розкривши дужки: (вільний) людина; (офіційний) згадка; (успішний) боротьба; (гучний) відгомін.

Наприклад: (синій) море - синє море.

3. Доберіть синоніми до слів: успішний, атакувати, заснувати, ймовірно.

Текстовий фрагмент:

Слово «козак» дійшло до нас із Середньої Азії від тюрків-кочівників, серед яких воно означало вільну незалежну людину. Перші козаки з'явилися на порогах Дніпра, ймовірно, в кінці 15 століття. $\langle\ldots>$ 
Постійні напади ворогів змусили козаків будувати укріплення для оборони. Спочатку вони заснували окремі городки або січі в різних місцях, в тому числі й на острові Велика Хортиця. Пізніше, у зв'язку $з$ посиленням наступу панів і кримських татар на Запоріжжя, козаки для згуртування своїх сил об'єдналися в одну Запорізьку Січ.

Козаки були вмілими воїнами не тільки на суші, а й на морі. Їх знамениті «чайки»* не боялися ні бурі, ні оснащених важкими гарматами турецьких галер, до яких вони сміливо підходили впритул і які брали на абордаж.

Бували випадки, що запорожці перевертали «чайки» догори дном, i, таким чином, наближалися до ворога, який нічого не міг зрозуміти. Він навіть не підозрював, що це насуваються човни з козаками. Потім серед турків ходили легенди про шайтанів* у шароварах, які з'явилися з самого дна моря.

Козаки нападали на турецькі й татарські міста, визволяли невільників, вели успішну боротьбу 3 султанським флотом. Гучний відгомін про це дійшов до нас в народних думах, баладах і легендах.

* Шайтан (тюрк. sajtan 3 араб.) - чорт, диявол.

* Чайка - безпалубний плоскодонний човен запорізьких козаків XVI-XVII ст.

Післятекстові завдання:

1. 3'єднайте слова за змістом, утворивши правильні словосполучення:

Запорізька гармати

Важкі

боротьба

Успішна Січ

2. Утворіть прикметники від іменників: море, пан, козак, воїн, флот.

3. Дайте відповіді на питання:

Що означало слово «козак»?

Коли з'явилися перші козаки?

Що заснували козаки на острові Велика Хортиця?

Для чого козаки об’єдналися в Запорізьку Січ?

Якими були козаки?

Що робили козаки?

4. Перекажіть текст.

Кожен поданий текст обов'язково супроводжується коротким словником, ілюстративним матеріалом, що дозволяє студентам у процесі навчання отримувати візуальне уявлення про зміст тексту, використовується роздавальний матеріал (фотографії, грошові знаки, чеки, квитки, вітальні, поштові та рекламні листівки, календарі тощо). Важливим є забезпечення іноземним студентам можливості доторкнутися до реальних предметів нового для них культурологічного середовища: одяг (вінок, вишиванка, шапка, шаровари, чоботи), меблі, посуд, репродукції картин та ін.

Використання лінгвокраїнознавчих прийомів у викладанні української мови як іноземної передбачає оволодіння студентами знаннями про культуру, історію, реалії та традиції країни; залучення до діалогу культур (іншомовної та рідної); усвідомлення суті явищ української мови та їх порівняння 3 рідною мовою; уміння вчитися (працювати з книгою, підручником, довідковою літературою, словниками тощо).

Реалізація лінгвокраїнознавчого підходу, його удосконалення тісно пов'язані зі створенням відповідних навчально-методичних посібників країнознавчої тематики: наприклад, «Україна: навчально-методичний посібник з лінгвокраїнознавства для іноземних студентів I-II курсів» [7], який активно застосовується в навчальному процесі в Луганському державному медичному університеті.

Отже, національно-культурний компонент навчання української мови як іноземної сприяє активізації комунікативно-пізнавальної діяльності студентів: вони мають бажання висловитися про прочитане, побачене або почуте, хочуть поспілкуватися стосовно подій, що відбуваються в країні, почути пояснення певних явищ та реалій. Результатом засвоєння лінгвокраїнознавчих матеріалів, за умови системного та цілеспрямованого їх застосування у викладанні української мови, $є$ вироблення в студентів соціолінгвістичної компетенції як складової іншомовної комунікативної компетенції, що дозволяє досягати повноцінної комунікації з представниками країни, мова якої вивчається.

Перспективним видається вивчення проблеми формування соціолінгвістичної компетенції на матеріалі виразів народної мудрості, етикетних формул українського народу.

\section{Література}

1. Алмазова Н. И. Когнитивные аспекты формирования межкультурной компетентности при обучении иностранному языку в неязыковом вузе : дис. ... д-ра пед. наук : 13.00.02 / Алмазова Надежда Ивановна. СПб., 2003. - 446 с. 2. Бронська А. Лінгвокраїнознавчий аспект у викладанні української мови як іноземної / Аліна Бронська // Дивослово. - 2000. - № 7. - С. 43-44. 3. Бронська А. Деякі принципи вивчення методики викладання української та російської мов як іноземних / Аліна Бронська // Рідна школа. - 2000. - № 2. - С. 22 24. 4. Верещагин Е. М. Язык и культура: лингвострановедение в преподавании русского языка как иностранного / Е. М. Верещагин, В. Г. Костомаров. - М. : Рус. язык, 1976. - 248 с. 5. Галенко А. М. Формування лінгвокраїнознавчої компетенції на матеріалі поетичних творів / А. М. Галенко // Вісник Луганського національного університету ім. Тараса Шевченка. - 2011. - № 6 (217) : Філол. науки. - Ч. ІІ. С. 100-108. 6. Смолінська О. Лінгвокраїнознавство у навчанні української мови як іноземної / Олеся Смолінська // Рідна школа. - 2002. - № 2. - С. 43-45. 7. Україна : [навч.-метод. посібн. $з$ лінгвокраїнознавства 
для іноземних студ. I-II курсів] / Скрябіна Т. А., Максименко Г. А., Гречанова А. Ю. та ін. - Луганськ : ЛДМУ, 2011. - 80 c. 